\title{
-ING SUPPLEMENTIVE CLAUSES AND DISCOURSE PROMINENCE IN LITERARY JOURNALISM ${ }^{1}$
}

\author{
MaríA-Ángeles MartíneZ \\ Complutense University of Madrid \\ ma.martinez@filol.ucm.es
}

\begin{abstract}
This study explores the role of-ing supplementive clauses as markers of discourse prominence in literary journalism. These apparently minor linguistic units - "Using them as cups, they sip the filthy water" (Time, 14 January 2013: 18) - stubbornly resist sentence-level syntactic and semantic description (Hengenveld 1997; Greenbaum and Quirk 2007; Huddleston and Pullum 2007: 207; Biber et al. 2010: 829). However, suprasentential studies within a cognitive-functional paradigm suggest that phenomena such as profiling (Verhaert 2006) and discourse prominence (Martinez 2012) may be crucial to their understanding. In the analysis, based on a collection of reportages from the American journal Time, these constructions actually seem to be frequently attached to the most prominent discourse entities, and to often combine with one another in the bighlighting of sequences of logically connected events and situations. This indicates that they might intervene in referential and focus management in discourse.
\end{abstract}

Keywords: -ing supplementive clauses, foregrounding, literary journalism, narrative, discourse management, non-finite clauses.

1 A preliminary version of this proposal was presented at the Second International Conference on Discourse Analysis (IWoDa), held at the University of Santiago de Compostela on June 19-21, 2013. 


\title{
LAS CONSTRUCCIONES DE GERUNDIO NO-PERIFRÁSTICO Y LA PROMINENCIA DISCURSIVA EN PERIODISMO LITERARIO
}

\begin{abstract}
RESUMEN. El presente estudio contempla el papel de las construcciones de gerundio no-perifrástico en lengua inglesa como indicadores de prominencia discursiva en periodismo literario. Estas unidades lingüisticas - "Using them as cups, they sip the filthy water" (Time, 14 January 2013: 18) - son difíciles de describir desde la perspectiva de la sintaxis y semántica oracional (Hengenveld 1997; Greenbaum and Quirk 2007; Huddleston and Pullum 2007: 207; Biber et al. 2010: 829). Sin embargo, estudios supraoracionales dentro de paradigmas cognitivo-funcionales sugieren que fenómenos como la puesta de relieve (Verhaert 2006) y la prominencia discursiva (Martínez 2012) pueden ser cruciales en su análisis. Este estudio analiza una colección de reportajes periodísticos del semanario norteamericano Time, y parece indicar que estas construcciones se asocian a entidades prominentes en el discurso, pudiendo combinarse entre para resaltar secuencias lógicas de sucesos y situaciones. Por ello cabe considerar que estas construcciones intervienen en el control referencial y atencional del discurso.
\end{abstract}

Palabras clave: Construcciones de gerundio no-perifrástico, puesta de relieve, periodismo literario, discurso narrativo, oraciones no personales.

Received 29 May 2015

Revised version accepted 15 July 2015

\section{INTRODUCTION}

-Ing supplementive clauses are one type of detached circumstantial adjuncts which frequently challenge sentence-level syntactic and semantic description. However, recent research suggests that their linguistic behaviour may be closely related to the expression of cognitive prominence, both at sentence and at discourse level. The aim of the present study is to examine the discourse behavior of -ing supplementive clauses in literary journalism from a cognitive-functional standpoint that focuses on their role in the management of the flow of information in discourse.

According to Gómez González and García Varela, "it can be said that discourseorganizational patterns result from the effective 'management' of at least four distinct, though interrelated kinds of information: (i) rhetorical management, (ii) referential management, (iii) focus management, and (iv) thematic management" (2014: 87; italics as in the original). In their 2014 study, the authors explore the interaction of rhetorical and thematic management in news reports. The present paper focuses 
on narrative reportages as instances of literary journalism, and explores the role of -ing supplementive clauses in the referential and focus management of discourse, as previous studies (Verhaert 2006; Martínez 2012) suggest that these non-finite constructions bear a relation to, respectively, the cognitive processes involved in referential identification, and the perspectivized presentation of information as salient foreground.

Syntactically functioning as circumstantial adjuncts, these constructions pose several difficulties to sentence-level analysis. First, although the implicit subject of the non-finite form is supposed to be co-referential with the subject of the superordinate clause, non-co-referential cases do occur in discourse. A second problem concerns the ambiguous circumstantial meanings of these detached adjuncts in the sentence, which are variously labelled as temporal, concessive, causal, conditional, result, manner, or reason (Hengeveld 1997: 154155; Greenbaum and Quirk 2007: 328; Huddleston and Pullum 2007: 207-209; Biber et al. 2010: 782-783, 820-829). Finally, although syntactic subordination tends to stand in an unmarked association with semantic background (Hopper and Thompson 1980; Thompson 1987), -ing supplementives recurrently challenge this connection, showing a striking tendency to co-occur with the grammar of prominence (Martínez 2012). Some studies, however, have noted that these sentence-level inconsistencies smoothly fit into place when the construction is approached from the cognitive standpoints of profiling (Verhaert 2006) and discourse foregrounding (Martínez 2012) in fictional narrative. The present study looks into the discourse behaviour of -ing supplementive clauses in journalistic reportages, with the aim of investigating whether their association with cognitive prominence also holds in genres other than fictional narrative.

The paper is organized as follows. First, I will briefly review the nature of literary journalism as a blend of factuality and fictionality. Then, I will revisit some of the controversies surrounding the grammatical description of -ing supplementives, including attempts at accounting for their formal features in terms of discourse function rather than sentence syntax and semantics. This will be followed by the analysis of a collection of reportages from the American journal Time, which will primarily focus on the connection between -ing supplementive clauses and the linguistic expression of prominence in terms of transitivity processes, modality, and implied subject reference. Additionally, the analysis will try to identify discourse relations across sentences containing -ing supplementive clauses within a given reportage. The results indicate that these subordinate constructions not only recurrently co-occur with the language of perspectival foregrounding, but might also signal out sentences which, despite not being adjacent, show tight cohesive links and discourse coherence. 


\section{NEWS REPORTS AS NARRATIVES: LITERARY JOURNALISM}

Literary journalism is the term used to refer to the artful presentation of news reports, with an evident focus on "the creation of empathic relations with people" (Keeble and Tulloch 2012: 5). Many of the constitutive elements of narratives temporally located events bringing about changes of state; human or human-like participants; unified causal chains; narratorial mediation; eventfulness; emplotment; tellability (Herman 2002; Fludernik 2009; Ryan 2007; Prince 2008; Herman 2008; Abbott 2015) - are actually present in most news reports. Maybe this is why researchers into media language describe journalists as 'professional story-tellers', explaining that "Story-telling and the use of narrative templates are fundamental means by which reporters give meaning to their articles" (Berning 2011: 17).

It is interesting to note that the narrative nature of news reports has often been approached in terms of rhetorical organization, with attempts at identifying structural components in line with Labov's (1972) six stages of oral narratives: abstract, orientation, complicating, action, evaluation, result or resolution, and coda. In this tradition, to be traced back to Vladimir Propp's studies of folk tales (1928), authors like Bell (1991; 2005), and van Dijk (1986; 1988) focus on the formal internal structure of journalistic narratives, or, to use van Dijk's term, on 'news schemata'. More recent studies (Berning 2011; Keeble and Tulloch 2012; Berning 2013), look at the experiencing side, that is, at ways in which readers, viewers, or listeners are involved in mental processes of embodiment and storyworld projection. In this type of studies, narrative reportages are approached as instances in which journalists devote their efforts to prompting reader engagement and immersion. Actually, the narrative worldmaking power of journalistic discourse can be illustrated by testimonies of real world people who, on finding their lives reported by journalists, strongly object to "becoming characters in someone else's narrative" (Keeble and Tulloch 2012: 13).

But the fictional/factual debate remains in the air. For instance, it could be argued that fictional narratives project fictional worlds, while journalistic writing invariably involves "an assertion about truthfulness to verifiable experience" (Keeble and Tulloch 2012: 7). This view would entail, according to Berning, that "everything in the story, from people to places and events, has a referent in the real world, and thus an existence independent of the narrative" (2013: 5). But the term 'referent' is of a tricky nature here, because, although a story is definitely something different from the discourse in which it may be variously wrapped up, reference takes place in the mind (Sidner 1983; Garrod and Sanford 1988; Emmot 1997; Sanford and Emmot 2012) and, consequently, strictly speaking, referents are built in processors' minds and result from the interaction of discourse input and idiosyncratic, culturally determined world experiences and perceptions. In this sense, journalistic stories and their entities would be interpreted through reference to the mental representations prompted in processors' 
minds, independently from whether the entities and events in these situational models have verifiable existence in the real world. Embracing this debate, recent insights into journalistic writing tend to acknowledge the blending of the factual and the fictional into what Berning (2013) calls the 'fictual', as fact and fiction need not be the two members of a narrative dichotomy (Ryan 2004: 3-4). In fact, writers' subjectivity and, concomitantly, perspective, are imposed on the factual, verifiable real world event by the narrating voice in literary journalism. In this way, by virtue of being narrated, the real life state of affairs, with its situations, events, and participant entities, is projected into receivers' minds in a storyworld format, impinged with writers' and narrators' manipulative perspectivization - event sequencing, evaluative language, vantage point-, and malleable when exposed to further interpreting processes by individual readers.

These similarities in the processing of fiction and nonfiction make it possible to assume that journalistic narratives partake of the perspectivizing features of fictional narratives in that they should be expected to linguistically present certain characters and events as perceptually more salient in readers' minds, while backgrounding others. This suggests that -ing supplementive clauses might display a foregrounding discourse function here as well, signaling cognitive prominence as they are claimed to do in fictional narratives. In view of these arguments, the research hypotheses are that: a) in journalistic discourse -ing supplementive clauses are most frequently attached to prominent discourse entities; b) by virtue of this association, these nonfinite subordinates signal out prominent parts of the news narrative; and c) they thus serve to guide readers' processing activity by highlighting a conceptual path across the linguistic material.

\section{APPROACHES TO -ING SUPPLEMENTIVE CLAUSES}

-Ing supplementive clauses are defined as non-finite constructions syntactically functioning as circumstantial adjuncts (Greenbaum and Quirk 2007: 328; Huddleston and Pullum 2007: 207-209; Biber et al. 2010: 782-783, 820-82), or detached adverbial satellites (Hengeveld 1997: 154-155). They are usually separated from the main clause by a comma in writing, while sharing its temporal and subject reference, and may occur in initial, medial, or final position:

(1) Lying in the hospital that evening, she said she considered herself lucky. (Time, 29 September 2008: 39)

(2) In the corner of the room, a tiny baby-3 hours old-lay on a bed, wailing, swaddled in bright-colored African fabric (Time, 29 September 2008: 36)

(3) Former residents gather on the hills overlooking their destroyed homes, lighting incense and firecrackers. (Time, 1 December 2008: 33) 
Co-referentiality with the superordinate clause is spelled out in what is known as the matrix clause attachment rule, which goes as follows: "When a subject is not present in a non-finite verbless clause, the normal ATTACHMENT RULE for identifying the subject is that it is assumed to be identical in reference to the subject of the superordinate clause" (Greenbaum and Quirk 2007: 327). But nonco-referential -ing supplementive clauses, or 'dangling participles' (Huddleston and Pullum 2007: 207; Biber et al. 2010: 829), do occur in discourse, as in examples (4) and (5) below:

(4) Leaving the road, the deep-resin-scented darkness of the trees surrounded them. (Biber et al. 2010: 829).

(5) Driving to Chicago that night, a sudden thought struck me. (Greenbaum and Quirk 2007: 328).

In these examples, taken from mainstream grammars, the implicit subject of the non-finite clause does not coincide with the main clause subject, but with its object, in italics. However, this does not seem to leave readers in any doubt regarding reference allocation, provided they have the necessary access to context and cotext. Non-co-referential occurrences are considered grammatically incorrect, and seem to be banned by editors of quality press (van Gelderen 2002: 145; Greenbaum and Quirk 2007: 328; Biber et al. 2010), despite being used by prestige literary writers (Martínez 2012), and consistently processed by language users.

The second difficulty concerns the type of semantic content that -ing supplementive clauses contribute to the main clause. There is widespread agreement that these clauses function as adverbial complements, but their adverbial meanings may be as varied and frequently overlapping as temporal, concessive, causal, and conditional, as well as result, concurrency in time, manner, or reason. Greenbaum and Quirk claim that "The supplementive clause implies an accompanying circumstance to the situation described in the matrix clause" (2007: 328), but does "not signal specific logical relationships" (2007: 328). Biber et al. further explain that "Thus, rather than try to specify a single meaning for such clauses, we simply acknowledge them as showing a circumstance that supplements the action or state in the main clause" (2010: 820). As Hengeveld puts it, "We assume that there are not distinct (semantic) meanings of the [this] circumstantial satellite, but different (pragmatic) interpretations, co-dependent on contextual and situational clues" (1997: 82).

Addressing these inconsistencies, a few studies have approached -ing supplementive clauses from cognitive-functional standpoints that stress features other than sentence syntax and semantics. Verhaert (2006), for instance, studies 
these constructions in Spanish - construcción de gerundio no-perifrástico - , using a corpus of contemporary fictional narrative. Even though the author still focuses on the sentence-level relation between main and subordinate clause, she suggests that more attention should be paid to the cognitive import of this relation, as the supplementive clause seems to "orient the receiver towards the desired interpretation" (Verhaert 2006: 99; my translation) by specifying, highlighting, restricting, or even rectifying what is communicated in the main clause. In other words, the author stresses the profiling function of these subordinate clauses as main clause perspectivizers, and emphasizes the crucial way in which they contribute to guiding readers' processing activity. She even interprets their semantic indeterminacy as a challenge to the reader's cognitive effort and a chance to enhance it with idiosyncratic personal contributions.

Within a cognitive paradigm drawing on Langacker's (1987) and Talmy's (2000) work, Cristofaro defines subordination as "a particular way to construe the cognitive relation between two events, such that one of them (which will be called the dependent event) lacks an autonomous profile, and is construed in the perspective of the other event (which will be called the main event)" (2005: 2). The unmarked association between syntactic subordination and attentional background is also noted by Thompson (1987). However, Toolan (1990: 116119) questions the unmarked association between -ing supplementives and background in narrative discourse, providing examples from fictional narratives in which these non-finite clauses seem to encode, precisely, those events which move the narration forward. In this line, Martínez (2012) explores the discourse function of -ing supplementive clauses in a corpus of English fictional narrative prose, focusing on mental reference as key to the disambiguation of the implicit subject in non-co-referential instances. The author notes that these non-finite subordinates frequently display linguistic features traditionally associated with the presentation of information as foregrounded focus of attention (Hopper 1979; Wallace 1982; Hewitt 1995: 326; Talmy 2000: 315-316; Stockwell 2002; Cristofaro 2005; Kita 2008; Tsur 2009). These foregrounding features are MATERIAL transitivity processes, assertive modality, and the focalizer, or character through whose perspective the fictional world is presented, as referent for the implied subject, even if not coincident with the matrix clause subject. On these grounds, the author claims that, in non-co-referential cases, "the cognitive weight of the most prominent discourse referent overrides intrasentential syntactic constraints for the sake of referential continuity and recoverability" (Martínez 2012: 89).

The studies described above coincide in pointing out the foregrounding properties of -ing supplementive clauses in fictional narrative discourse. But fictional narratives usually tell stories about certain characters that are permanently activated in readers' 
mental representation of the fictional world. The question may thus arise of whether these subordinate clauses are connected to discourse prominence in other genre types, such as the non-fictional narratives found in journalistic reportages. The rest of the study will be geared towards addressing this question.

\section{METHODOLOGY}

The data on which the analysis is based consists in a collection of randomly selected reportages from the American weekly journal Time, amounting to an approximate 65,000 words. They cover a variety of topics--from economic and sociopolitical analysis to arts and leisure--, and were published between April 2008 and January 2013. The reports range from half a page to nine pages in length, including photos and images. The collection contains a total of 146 -ing supplementive clauses, which have been analysed using a combination of bottom-up and top-down techniques, as this methodology is usual in the computational identification and tagging of discourse units in large corpora (Afantenos et al. 2012: 2727).

The bottom-up part of the analysis focused on some of the grammatical features typically associated to linguistic foreground. As shown in Table 1, discourse entities profiled as semantic Figure (Talmy 1975; 2000) tend to be encoded using pronominal or zero anaphoric reference, while the foregrounding of events usually involves MATERIAL transitivity processes, assertive modality, perfective aspectuality, and the use of main clauses. Conversely, the linguistic devices associated with the presentation of discourse entities and events as part of the background are noun phrase reference, RELATIONAL transitivity processes, non-assertive modality, imperfective aspectuality, and syntactic subordination. -Ing supplementive clauses are intrinsically imperfective and subordinate, so the bottom-up analysis has focused on the three remaining features: reference, transitivity, and modality.

Table 1. The grammar of cognitive prominence in narrative discourse (Hopper 1979; Wallace 1989; Cristofaro 2005; Kita 2008).

\begin{tabular}{|l|l|}
\hline \multicolumn{1}{|c|}{ FIGURE } & \multicolumn{1}{c|}{ GROUND } \\
\hline Pronominal or zero anaphoric reference & Noun phrase reference \\
Material transitivity processes & Relational transitivity processes \\
Assertive modality & Non-assertive modality \\
Perfective aspectuality & Imperfective aspectuality \\
Main clause & Subordinate clause \\
\hline
\end{tabular}


Finally, the top-down analysis will try to identify discourse relations holding across sentences containing -ing supplementive clauses within a single reportage.

\section{PROMINENCE AND THE SYSTEMS OF TRANSITIVITY AND MODALITY}

The results of the bottom-up analysis quite consistently match those for fictional narrative in previous studies. Regarding the transitivity configuration of the clause (Halliday 2014), MATERIAL processes prove to be highly frequent (68.49\%; N=100), and so does assertive modality (93.22\%; N=136). Consider example (6) below:

(6) Former residents gather on the hills overlooking their destroyed homes, lighting incense and firecrackers for their kin entombed in the collapsed buildings and mud below. (Time, 1 December 2008: 33) (MATERIAL; Assertive).

Although less frequently, other process types can also be found, including RELATIONAL, VERBAL, BEHAVIOURAL and MENTAL, as in (7), (8), (9), and (10), respectively:

(7) Looking like the wacky love child of a treebouse and a UFO, the structure features a 19.5-m crescent sofa and a hot pink canopied wedding bed. (Time, 14 January 2013: 44) (RELATIONAL; Non-Assertive).

(8) In nearby Basilea, a group of women sit inside a home, talking about the pond they are being paid to dredge out and revive. (Time, 29 October 2012: 38) (VERBAL; Assertive).

(9) In the corner of the room, a tiny baby - 3 hours old-lay on a bed, wailing, swaddled in bright-colored African fabric. (Time, 29 September 2008: 36) (BEHAVIOURAL; Assertive).

(10) In Congress, some Republicans will want to cooperate with president-elect Barack Obama, heeding the voters' desire for bipartisanship. (Time, 1 December 2008: 21) (MENTAL, Assertive).

As can be observed in Figure 1 and in Tables 2 and 3, MATERIAL transitivity processes are, actually, the most frequent in the two genres considered $(68.49 \%$ news and $44.85 \%$ fiction), although the higher degree of agency attribution in journalistic narratives, reflected in a higher percentage of MATERIAL processes, seems to be replaced in fictional narrative by lower agentive control and a reliance on externally perceptible behaviours, expressed as BEHAVIOURAL processes cry, wail, shrug, blink--(4.40\% news vs. $23.40 \%$ fiction). It may also be worth noting that the presence of MENTAL processes is noticeably higher in those -ing supplementives occurring in fictional narrative (2.73\% news vs. $17.27 \%$ fiction). 
This may be explained by the fact that, in fictional narrative, perspectivization tends to be realized through various forms of thought presentation, so that it is logical to expect a higher percentage of verbs expressing mental activity. Judging from the data, however, in journalistic narratives epistemic modality relies more heavily on hearsay evidential, as shown in the higher presence of VERBAL processes (11.64\% news vs. 6.68\% fiction). Description, realized by RELATIONAL processes, although scarce in the -ing supplementives analysed in the two genres, seems to be slightly more frequent in journalistic narrative (13.08\%) than in fiction (7.52\%).

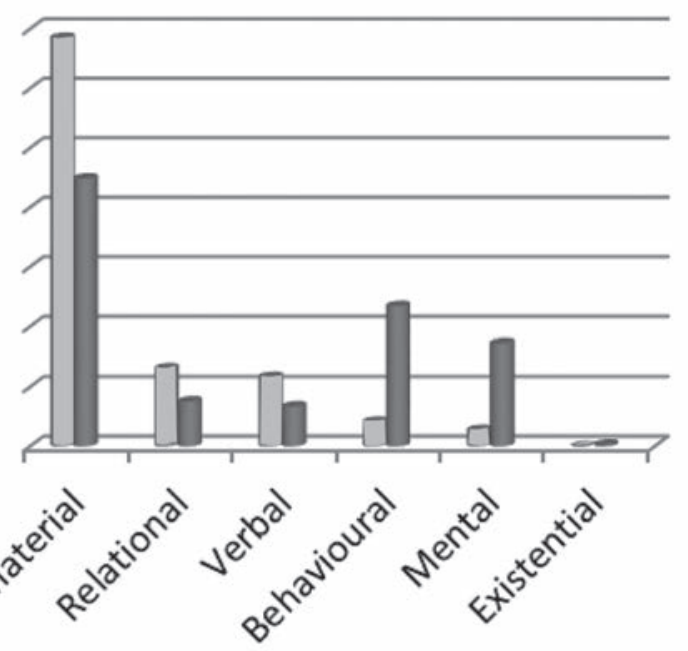

$\square$ Journalistic discourse

- Fictional narrative

Figure 1. Transitivity processes in -ing supplementive clauses: Journalistic reportages and fictional narrative.

Table 2. Transitivity processes in -ing supplementive clauses.

Journalistic discourse.

\begin{tabular}{|lrl|}
\hline PROCESS TYPE & $\%$ & \\
MATERIAL & 68.49 & $(\mathrm{~N}=100)$ \\
RELATIONAL & 13.08 & $(\mathrm{~N}=19)$ \\
VERBAL & 11.64 & $(\mathrm{~N}=17)$ \\
BEHAVIOURAL & 4.10 & $(\mathrm{~N}=6)$ \\
MENTAL & 2.73 & $(\mathrm{~N}=4)$ \\
TOTAL & 100 & $(\mathrm{~N}=146)$ \\
\hline
\end{tabular}


Table 3. Transitivity processes in -ing supplementive clauses. Fictional narrative discourse. (Adapted from Martínez 2012)

\begin{tabular}{|lrl|}
\hline PROCESS TYPE & $\%$ & \\
MATERIAL & 44.85 & $(\mathrm{~N}=161)$ \\
RELATIONAL & 7.52 & $(\mathrm{~N}=27)$ \\
VERBAL & 6.68 & $(\mathrm{~N}=24)$ \\
BEHAVIOURAL & 23.40 & $(\mathrm{~N}=84)$ \\
MENTAL & 17.27 & $(\mathrm{~N}=62)$ \\
EXISTENTIAL & 0.28 & $(\mathrm{~N}=1)$ \\
TOTAL & 100 & $(\mathrm{~N}=359)$ \\
\hline
\end{tabular}

The high occurrence of MATERIAL processes in the two genres is matched by a remarkably high presence of assertive modality (Table 4 and Figure 2). It might be worth noting that Non-Assertive modality seems to be slightly more frequent in fictional narratives (16.16\%) than in journalistic reportages (6.78\%), probably also due to the high presence in the former of unreliable, unobservable, unverifiable inner speech and thought presentation.

Table 4. Modality in journalistic and fictional narrative discourse (the latter adapted from Martínez 2012).

\begin{tabular}{|l|c|c|}
\hline MODALITY TYPE & JOURNALISTIC DISCOURSE & FICTIONAL PROSE \\
\hline ASSERTIVE & $93.22 \%(\mathrm{~N}=136$ & $83.84 \%(\mathrm{~N}=301)$ \\
\hline NON-ASSERTIVE & $6.78 \%(\mathrm{~N}=10)$ & $16.16 \%(\mathrm{~N}=58)$ \\
\hline TOTAL & $100 \%(\mathrm{~N}=146)$ & $100 \%(\mathrm{~N}=359)$ \\
\hline
\end{tabular}

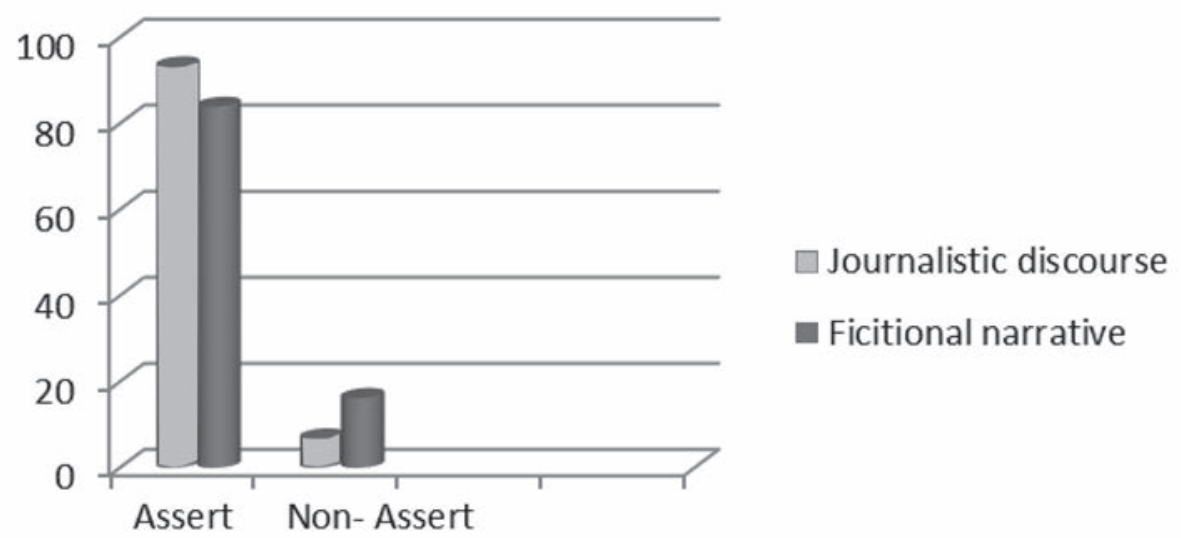

Figure 2. Speech act modality in -ing supplementive clauses: Journalistic reportages and fictional narrative. 
This part of the analysis thus suggests an unmarked association of -ing supplementive clauses with certain foregrounding devices. Additionally, it also highlights certain genreassociated variations, such as the higher presence in fictional narrative of MENTAL and BEHAVIOURAL transitivity processes, as well as of Non Assertive modality; and the overwhelming predominance of MATERIAL processes in journalistic narratives, together with a higher reliance on RELATIONAL and VERBAL processes.

\section{FOREGROUNDED ENTITIES AS REFERENTS FOR THE IMPLICIT SUBJECT}

As pointed out by Martínez (2012: 81), in fictional narratives the mental representation that the reader entertains for the foregrounded focalizer, or character through whose perception the fictional world is presented, is the most frequent referent for the implied subject of -ing supplementives. Although the percentage - 39.37\% -, is not overwhelmingly high, focalizers function as implied subjects for these constructions much more often than secondary characters, even if attention is occasionally geared to these within narrative progression. In the case of journalistic narratives, however, referential prominence seems to be more tightly packed around the entity that the reportage is about, usually featuring as such in its title. In fact, foregrounded entities function as referents for the implied subject in 122 (83.52\%) of the 146-ing supplementives in the analysis. Furthermore, the focus status of this foregrounded mental referent seems to be of three types: permanent prominence, lexical chain prominence, and metonymic prominence. Implied subject referents of a non-prominent nature have also been classified into three further minor types: an entity with temporary discourse prominence; a newly introduced entity; and a non-co-referential implicit subject. All of them are presented in Table 5, and will be further discussed below.

Table 5. Types of discourse referent as implied subject in -ing supplementive clauses in journalistic discourse.

\begin{tabular}{|c|c|}
\hline PROMINENCE TYPE & $\%$ \\
\hline $\begin{array}{l}\text { 1. Foregrounded discourse referent } \\
\text { 1.1. Permanent prominence } \\
\text { 1.2. Lexical chain prominence } \\
\text { 1.3. Metonymic prominence } \\
\end{array}$ & $\begin{array}{l}83.52(\mathrm{~N}=122) \\
42.46(\mathrm{~N}=62) \\
21.23(\mathrm{~N}=31) \\
19.86(\mathrm{~N}=29) \\
\end{array}$ \\
\hline \begin{tabular}{|l} 
2. \\
$\begin{array}{l}\text { Referent with temporary discourse prominence (not } \\
\text { mentioned again) }\end{array}$
\end{tabular} & $10.96(\mathrm{~N}=16)$ \\
\hline $\begin{array}{l}\text { 3. New referent introduction (After introduction, referent } \\
\text { becomes focus of attention) }\end{array}$ & $2.05(\mathrm{~N}=3)$ \\
\hline 4. Non-co-referential implicit subject (Dangling participles) & $2.74(\mathrm{~N}=4)$ \\
\hline TOTAL & $100(\mathrm{~N}=146)$ \\
\hline
\end{tabular}




\subsection{FOREGROUNDED DISCOURSE REFERENT: PERMANENT PROMINENCE}

In a majority of cases (83.52\%), the implied subject of the -ing supplementive clause is co-referential with the entity in focus in the flow of discourse. In the analysis, this foregrounded status seems to be of three types. Most frequently (42.46\%), the entity functioning as mental referent for the implied subject is the permanent focus of attention in the reader's mental model of the situation. Permanent prominence usually occurs in one-page or shorter reports about one specific public individual, or in thirty-line or more stretches about one single individual, inserted in a longer reportage. The most straightforward instances are those in which an entity is explicitly announced as topic in the reportage head or subhead, as in examples (11) and (12) below. These cases amount to 49 (40.16\%) of the 122 prominent referent entities in the data:

(11) Sitting at the crossroads of three continents, Greece has a long history of immigration. (Head and subhead: "Immigrant Odyssey. Fortens of thousands of desperate immigrants from central Asia and the Middle East, the Greek islands have become the new back door into Europe. As authorities in Athens struggle to cope with the influx, can Greece regain control of its borders?") (Time, 1 December 2008: 39).

(12) Mixing pragmatism with relentless energy, Nicholas Sarkozy has brought his undeniable lawyerly talents for persuasion and negotiation to French diplomacy. (Head and subhead: "At Home Abroad. Nicholas Sarkozy's diplomatic panache has charmed the French republic, but it hasn't yielded only success”.) (Time, 29 September 2008: 33).

In other cases, permanent prominence involves an entity or entities that, despite not being mentioned in the head or subhead of the reportage, nevertheless become the focus of attention for thirty lines or more, acquiring prominence in a specific narrative sub-episode. This is the case in examples (13), (14), and (15), from a four-page reportage covering the aftermath of the earthquake that hit China in 2008. This reportage includes the telling of the individual stories of three survivors, presented in succession, each ranging from 38 to 48 lines in length, and each containing one -ing supplementive clause with the respective surviving witness as mental referent for the implicit subject:

(13) Zhang now heads the Beichuan Department of Commerce, working to attract new businesses and industrial development. (Time, 1 December 2008: 34) (48-line episode about Zhang). [33 lines]

(14) It is with a similar determination that Lu fights for an answer to why the Beichuan No. 1 Middle School caved in, crushing his daughter. (Time, 1 December 2008: 34) (43- line episode about Lu). [79 lines]

(15) Luo walked five days with an injured foot and no shoes, braving runaway boulders and mudslides to make it to safety. (Time, 1 December 2008: 35) (38-line episode about Luo). 
In such cases, the mental referent has also been considered to be a prominent discourse entity, as it is the focus of attention within a lengthy narrative subepisode.

\subsection{FOREGROUNDED DISCOURSE REFERENTS: LEXICAL CHAIN PROMINENCE}

In the second type of reference to an entity presented as prominent, the activated referent is maintained in the foreground of the reader's attention by lexical cohesion chains including phenomena such as synonymy, hyper- or hyponymy, and semantically related terms (Halliday and Hasan 1976), as in example (16). These referents amount to $21.23 \%$ of the total. Consider example (6), which occurs in a five-page reportage on the USA financial crisis entitled "The Price of Greed":

(16) One weekend, the Federal Government swallows two gigantic mortgage companies and dumps more than $\$ 5$ trillion—yes, with a $t$-of the firm's debt onto taxpayers, (1) nearly doubling the amount Uncle Sam owes to his lenders.

[...6 lines...]

Then, (2) having sworn off bailouts by letting Lehman fall and wiping out its shareholders, the Treasury and the Fed reverse course for an $\$ 85$ billion rescue...

[4 paragraphs...]

This latest go-round featured hedge-fund operators,..., who devised and plugged in those new financial instruments, (3) creating a financial Frankenstein the likes of which we had never seen.

[...2 paragraphs]

It was safe too-or so Wall Street claimed—because investors worldwide were buying U.S. financial products, (4) thus spreading risk around the globe". (Time, 29 September 2008: 18-21).

Here, the lexical items in italics - the Federal Government; the Treasury and the Fed; hedge-fund operators; investors worldwide - constitute a lexical chain (Halliday and Hasan 1976) connecting the implied subjects of the four -ing supplementive clauses which succeed one another across two pages, highlighting the main actors in the crisis. What seems peculiar about this example is that not only do the four non-finite clauses display tight participant continuity, even though they are paragraphs apart, but also that, when displaced from the whole of the text and put artificially together as they have been here, the result seems to be a highlighted pathway across the main story line in the financial narrative of the crisis, the -ing clauses acting as flashlights that mark the reader's cognitive way along the main events in the story skeleton. 


\subsection{FOREGROUNDED DISCOURSE REFERENTS: METONYMIC PROMINENCE}

Of particular interest as well seem those cases in which the implied subject, duly co-referential with the matrix clause, seems to be non-co-referential with the entity in focus. But, in fact, when these examples are observed in detail, it becomes apparent that the foregrounded participant, the one on whom the weight of the reader's attention is being invited to fall, metonymically continues to be the referent in focus in the form of a possessive pronoun or noun. These have been considered cases of metonymic prominence (19.86\%). In example (17), taken from a one-page report on one of the presidential candidates for the 2008 U.S. elections, John McCain, pronominal his helps keep the currently activated referent as focus, even though the surface matrix clause and supplementive clause subject is not himself, but His campaign:

(17) His [McCain's] campaign has been a ceaseless assault on his opponent's character and policies, featuring a consistent-and witting—disdain for the truth. (Time, 29 September 2008: 17).

Example (18) presents another case of metonymic prominence. It occurs in a thirty-line long sub-narrative that closes a three-page reportage on immigration from Asia and the Middle-East into Europe. This sub-narrative tells the story of Said, a young immigrant from Afghanistan, and his vicissitudes until he was eventually stopped in Greece. In the three paragraphs containing his adventure, there are three -ing supplementive clauses. One of them, (18), relies on the high activation of Said, introduced eleven lines earlier, as metonymically implied referent for His brother, who is not mentioned again. Said's prominence is reminded seven lines later (19):

(18) His [Said's] brother, 29, made his way to Europe via Russia a decade ago, settling in the Netherlands. (Time, 1 December 2008: 40).

(19) Pulling out his 30-day expulsion order written in Greek, he [Said] mulls over his options. (Time, 1 December 2008: 40).

\subsection{TEMPORARY DISCOURSE PROMINENCE}

In some cases, the implied referent is not a permanently activated discourse entity, but one that, notwithstanding, is expected to capture the reader's attention in the short stretch where it occurs, usually a single sentence, and is never mentioned again. This 
temporary discourse prominence occurs much less frequently in the data (10.96\%). In (20), for instance, the referent for the implied subject, a nurse, has just been introduced, becoming focus in short-term memory, but this is the only time she is mentioned:

(20) Finally the woman's aunt handed some 250,000 leones (about \$85) to a nurse, who counted the banknotes before jamming them into her pocket, explaining to me that the money was 'for drugs and to pay the doctor.' (Time, 29 September 2008: 39).

Within this category are those cases in which the primed discourse referent seems to be the exophoric addressee, either real or implicit reader, as in examples (21) and (22):

(21) Reading it now, with the burden of hindsight, one sees that 'Infinite Jest' is ominously infested with suicides. (Time, 29 September 2008: 56).

(22) You could spend a nice year trotting from Ditchley Park in Oxfordshire to Salzburg, from the Italian lakes to German castles, doing notbing butponder in earnest detail the state of the Atlantic alliance. (Time, 1 December 2008: 23).

From the standpoint of discourse reference, it could be claimed that hearer and speaker are here assumed as temporary focus of attention, bringing to mind one of the few cases in which matrix clause non-co-referentiality is accepted, namely, entrenched instances such as considering or taking into account (van Gelderen 2002: 145; Huddleston and Pullum 2007: 329). However, examples (21) and (22) do not contain entrenched expressions, but ordinary implicit subjects, duly co-referential with an inclusive pronoun in the superordinate clause - one and you - which explicitly invites reader involvement. In fact, many entrenched occurrences might also be considered to belong to the reader-as-referent type, in which frequency of use has made non-co-referentiality seem natural. This would be the case in example (23), where the non-co-referential subject of Going forward seems to imply both speaker and hearer, and, in this way, may help promote hearer involvement:

(23) Going forward, there's one particularly creepy thing to keep in mind. (Time, 29 September 2008: 18).

\subsection{NEW REFERENT INTRODUCTION}

New referent introduction refers to those cases, rare in the data (2.05\%), in which the non-finite clause accompanies the first mention of a new discourse entity, henceforth presented as the focus of attention of the reportage for a minimum of 20 lines: 
(24) In a hospital ward in Freetown, the capital of Sierra Leone, Fatmata Conteh, 26, lay on a bed, having just given birth to ber second child. (Time, 29 September 2008: 36).

(25) Bobbing in the open sea 50 feet away are five young men, shielding their eyes from the sudden beam of light. (Time, 1 December 2008: 39).

Example (24) introduces Fatmata Conteh, a victim of the pitiful state of Sierra Leone's health system, whose story will be told over the next 26 lines. The same happens with the illegal immigrants in (25), whose story will occupy the following thirty-three lines.

\subsection{NON-CO-REFERENTIAL SUBJECT}

Even though supposedly banned by prestige editors, there are four cases of non-co-referential implied subjects in the data, in which the implicit subject of the non-finite verb differs from the matrix clause subject. Non-co-referential cases can also be found in quality literary prose (Martínez, 2012), though this might be explained by the relative stylistic and artistic freedom of fiction writers, compared to the likely editorial constraints imposed on journalists. However, these cases prove to occur in journalistic reportages as well:

(26) Cross-country flights of up to 120 miles $(200 \mathrm{~km})$ are possible, soaring over the vast expanse of the Dhauladhar range, and taking in the stunning countryside of tea plantations, forests and fields. (Time, 1 December 2008: 53).

There are two -ing supplementive clauses here. The first - soaring over the vast expanse of the Dhauladhar range - could be considered to share the matrix clause subject, cross-country flights, although co-reference seems slightly forced, as it is people or machines that soar over places, not the flights themselves. In the next -ing clause, however, taking in the stunning countryside [...], the incongruity becomes even stronger, as the semantics of flights can no longer be stretched to assume that flights can take in any sort of input, and the most likely understood implied subject is the person or persons that are flying. This metonymic extension is reinforced by the fact that, in this particular report--a half-page review of paragliding over the Hymalayas in the leisure section of the journal--the pronouns you/your and the NP flyers with several zero anaphoric counterparts frequently highlight the reader-as-potential-flier as entity in focus. With such a clearly salient figure in mind, the reader probably has no difficulty in making the conceptual leap involved in metonymically swapping flights for flyers, or even for I-as-flyer.

The relative frequency of occurrence of these seven types of discourse referents for the implied subject of -ing supplementive clauses is presented in Figure 3. As 
can be observed, the most frequent cases involve referents which are currently foregrounded in readers' minds, in what I have called, respectively, permanent, lexical chain, and metonymic prominence reference. Referents mentioned just once and not related to the prominent entity either metonymically or via lexical cohesive devices - temporary discourse prominence - occur much less frequently. Also few are the cases in which the first mention of an implied subject referent bound to become focus of attention is accompanied by an -ing clause, in a new referent introduction function. Finally, there are also a few cases of non-co-referentiality in which the implicit -ing subject has a referent different from that of the matrix clause subject.

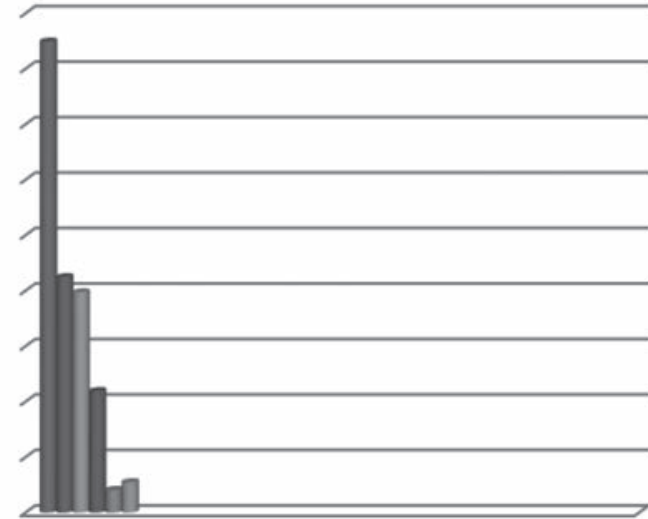

\section{- Permanent prominence}

- Lexical chain prominence

Metonymic prominence

- Temporary prominence

New referent introduction

n Non-co-referential

Figure 3. Discourse referent types in -ing supplementive clauses.

The bottom-up part of the analysis thus confirms a predominance of grammatical forms associated to the linguistic expression of prominence: MATERIAL transitivity processes, assertive modality, and the foregrounded discourse entity as implicit subject referent. This supports claims regarding the foregrounding function of -ing supplementive clauses in journalistic discourse, as well as their connection to topic continuity.

\section{TOP-DOWN ANALYSIS: DISCOURSE RELATIONS}

This part of the analysis will focus on those reportages containing more than one -ing supplementive clause. The purpose is to find out whether two or more sentences containing -ing supplementives as adjuncts may be interconnected by 
discourse relations, as seems to be the case, for instance, in example (16) above. This could provide grounds for considering -ing supplementive clauses as markers of basic discourse units, liable to be further combined into larger units of a prominence nature. - Ing basic units would be defined as sentences containing an -ing supplementive clause and co-occurring with other similar sentences to which they are linked by logical discourse relations, holding across intervening material of varying lengths, from a few lines to several paragraphs. In fact, many of the examples presented so far suggest that such relations do exist, and point to the fact that they may be of two main types: Additive and Counterpoint.

\subsection{ADDITIVE RELATION}

The sentences containing an -ing supplementive clause that co-occur in a single reportage may add up elements which together highlight the story skeleton, or main story line. The cases of Addition in the data are of two types: sequential and summative.

In sequential addition, the events or situations presented in the co-occurring ing units follow one another chronologically in the storyworld projected in readers' minds. This is the case in (16) above, from a five-page reportage on the outbreak of the 2008 financial crisis in the US. Notice that the four -ing supplementive clauses in this reportage occur in sentences which are often paragraphs apart, but which together provide an astonishingly coherent and complete summary of the stages which led to the disaster.

Conversely, in summative addition, co-occurring -ing units present mutually complementary events which are not necessarily sequenced in time, but which elaborate on one another, showing tight conceptual unity. Example (27) presents the three -ing supplementive clauses occurring at, respectively, the beginning, middle, and end of a one-page reportage about the then recently deceased actor Charlton Heston:

(27) In the era of the movie epic, he [Heston] was the iconic hero, adding to these films millions in revenue, plenty of muscle and 10IQ points.

[...24 lines...]

Director Cecil B. DeMille immediately saw the actor's appeal, casting him in The Greatest Show on Earth, then giving him the role of Moses in The Ten Commandments. [... 40 lines...]

At the 2000 NRA convention, he [Heston] invoked his own Moses, hosting a rifle above his head and proclaiming that presidential candidate Al Gore could remove the gun only by prying it 'from my cold, dead hands.'

(The Epic Man: From iconic movie hero to gun advocate, Charlton Heston embodied both our grandest and our most ornery beliefs; Time, 21 April 2008: 47). 
As can be observed, even though these sentences are lines apart, and despite the great amount of intervening material, the -ing units not only are astonishingly cohesive, but also provide a coherent summary of the key points on which the journalist grounds his narration. Another example of a summative addition relation can be found in (28), which occurs in a reportage on US retailer stores entitled "Black Friday is Looking Blue". Here, three out of four -ing supplementive clauses have as implied subject the lexical chain made up by two store names, Wal-Mart and Sears and Radio Shack, and the hypernym Many stores. Once again, these three -ing units are evenly distributed across the two pages of the reportage, and again the length of intervening material does not obscure the tight meaning relationship between them. In fact, as in previous examples, the larger -ing complex seems to highlight a cognitive path across what might be the key point in this reportage, namely, stores' tricks to cope with the crisis:

(28) Power discounter Wal-Mart launched Operation Main Street, (1) presenting a new run of markdowns every week until Christmas.

[...3 lines...]

Sears and Radio Sacks are urging eco-conscious consumers to suck their powersucking old equipment, (2) offering gift certificates for the trade in value.

[...5 paragraphs...]

Many stores have gone further, (3) lowering inventory levels as much as $18 \%$.

(Time, 1 December 2008: 26-27).

\subsection{COUNTERPART RELATION}

-Ing units may also contain elements which interact in the development of the argumentative line of a reportage, by alternating viewpoints from two or more sources, as in examples (29) and (30) below. (29) occurs in a two-page article on cyclist Lance Armstrong and the allegations of doping by US Anti-Doping Agency (USADA) that he had to face. The reportage, which has the tell-telling title Armstrong's Ahab, revolves around the mutual accusations of Armstrong and USADA CEO Travis Tygart, who led the agency's investigation. This is the way in which the six co-occurring -ing units in this reportage combine with one another into an -ing complex, providing the reader with different key perspectives on the narrated events, in such a way that, when assembled together as below, these six sentences present the contenders' respective viewpoints:

(29) 'Everybody wants to know what I am on. What am I on? I am on my bike, busting my ass six hours a day.' [Armstrong as speaker and referent]

[...36 lines...] 
'At every turn, USADA has played the role of a bully, threatening everyone in its way and challenging the good faith of anyone who questions its motives and its methods [...].' [Armstrong as speaker; Tygart as metonymic referent]

[...4 lines...]

Tygart's resposte has been to unleash an avalanche of evidence, from e-mails and bank records to eyewitness accounts, drawing inferences of guilt that lacked any nuance of ambiguity. [Tygart as metonymic referent]

[...47 lines...]

USADA is an independent agency created in 2000 to take over anti-doping operations for the U.S. Olympic Committee, allowing it to avoid any potential conflicts of interest. [Tygart as metonymic referent]

[...17 lines...]

And even if he [Tygart] didn't think it was personal, the Armstrong team did, mentioning bim by name, calling him out. [Armstrong as metonymic referent]

[...18 lines...]

'That's not a justification to ignore it,' Tygart says, pointing to rationalizations that led to ethical breakdowns at athletic programs at Penn State [...]. [Tygart as speaker and referent]

(Armstrong's Ahab, Time, 29 October 2012. 14-15).

Consider now example (30), taken from a reportage on the 2008 presidential campaign in Zimbabwe, and which also exemplifies a counterpoint relation, as the four -ing units it contains are used to present the respective positions of the two contenders, former president Robert Mugabe and elected candidate Morgan Tsvangirai:

(30) In 2002 he [Morgan Tsvangirai] was widely thought to have won Zimbabwe's presidential election, beating the country's tyrannical leader, Robert Mugabe. [Tsvangirai as referent] [contiguous]

But according to most independent observers, Mugabe had the results fixed, extending bis tenure as Zimbabwe's only ruler since independence in 1980. [Mugabe as referent] [18 lines]

Mugabe, 84, is demanding a recount and a runoff for the presidency, fueling fears of another vote fix. [Mugabe as referent]

[13 lines]

Speaking to TIME by phone from an undisclosed location in Zimbabwe, he [Tsvangirai] said, 'We need to shift from focusing on our independence and start focusing on our prosperity and freedom.' [Tsvangirai as speaker and referent] (Taking On the Big Man, Time, 29 September 2008: 34).

Once again, physical discontinuity does not prevent these four -ing units from forming an -ing complex which displays not only conceptual coherence, but also remarkable internal textual cohesion, despite the length of the intervening material 
between its constitutive -ing units. This is reflected in lexical repetition (fixedfix; independence-independence; presidential-presidency) and referential cohesion (had the results fixed-another vote fix). In fact, a vast majority of the co-occurring -ing units in the data are interconnected by either an Additive or a Counterpoint relation, but further research might reveal further logical connections.

\section{CONCLUSION}

This study has explored the role of -ing supplementive clauses in the referential and focus management of discourse, with the aim of finding out whether the association with foregrounding and profiling that these circumstantial adjuncts seem to display in fictional narratives is genre-specific, or whether it holds in journalistic discourse as well. Of special concern has been the cognitive prominence of implicit subject referents, as journalistic discourse does not usually revolve around a single main character, but deals with a variety of topics and entities. In this respect, the -ing supplementive clauses in the data not only tend to predominantly contain MATERIAL transitivity processes and Assertive modality, traditionally connected to information foregrounding, but also seem to be recurrently attached to the prominent discourse entity that the reportage is about. This might be seen as challenging the default association between syntactic subordination and linguistic background, and could point to the need to approach the study of these detached constructions from a cognitive-functional, suprasentential viewpoint.

A further concern has been the extent to which, when co-occurring in connected discourse, -ing supplementive clauses may function as markers of -ing units, or sentences containing one or more of these non-finite clauses, liable to be combined into complexes of a prominence marking nature. The analysis actually shows that high internal cohesion and coherence frequently hold across the sentences containing -ing supplementives within a single reportage, regardless of the length of intervening material. Furthermore, two types of discourse relations, Additive and Counterpoint, have been identified as joining these sentences, or -ing units, into -ing complexes. Moreover, the latter seem to highlight key points in the reportage, confirming that the physical distance between co-occurring -ing units need not be an obstacle to referential continuity and cognitive unity.

To sum up, from a syntactic viewpoint, -ing supplementive clauses are subordinate structures in the sense that they depend on a main clause. However, at discourse level, these non-finite constructions seem to deserve further research in connection to the interaction of referential and focus management. Although further research should use larger corpora and explore a wider variety of genres, this study may contribute a few useful insights and research tools to this endeavor. 


\section{REFERENCES}

Afantenos, S. et al. 2012. "An empirical resource for discovering cognitive principles of discourse organisation: the ANNODIS corpus". Proceedings of the Eighth International Conference on Language Resources and Evaluation (LREC'12). European Language Resources Association ELRA. 2727-2734.

Abbott, H. P. 2015. "Narrativity". the living handbook of narratology. Eds. Peter Hühn et al. Hamburg: Hamburg University Press.

Bell, A. 1991. The Language of News Media. Oxford: Blackwell.

Bell, A. 2005. "News stories as narratives". The Language of Time: A Reader. Eds. I. Mani, J. Pustejovsky and R. Gaizauskas. Oxford: Oxford University Press. 397409 .

Berning, N. 2011. Narrative Means to Journalistic Ends. Hamburg: Verlang.

Berning, N. 2013. "Fictual matters. Narration as a process of relating in M. Bowden's Blackhawk Down (1997)". Diegesis 2.2: 1-19.

Biber, D. et al. 2010. Grammar of Spoken and Written English (3rd edn). London: Longman.

Cristofaro, S. 2005. Subordination. Oxford: Oxford University Press.

Emmott, C. 1997. Narrative Comprehension: A Discourse Perspective. Oxford: Oxford University Press.

Fludernik, M. 2009. An Introduction to Narratology. London and New York: Routledge.

Garrod, S. and T. Sanford. 1988. "Thematic subjecthood and cognitive constraints in discourse structure". Journal of Pragmatics 12: 519-534.

Gómez González, M. Á. and A. P. García Varela. 2014. "Discourse-organizational patterns in English and Spanish. Some notes on the thematic management of news reports". Revista Española de Lingüística Aplicada 27 (1): 87-117.

Greenbaum, S. and R. Quirk. 2007. A Student's Grammar of the English Language (3rd edn). London: Longman.

Halliday, M. A. K. 2014. An Introduction to Functional Grammar(3rd edn). London and New York: Routledge.

Halliday, M. A. K and R. Hasan. 1976. Cohesion in English. London: Longman.

Hengeveld, K. 1997. The Theory of Functional Grammar. Part 2. Complex and Derived Constructions. Berlin, New York: Mouton de Gruyter.

Herman, D. 2002. Story Logic: Problems and Possibilities of Narrative. Lincoln: University of Nebraska Press. 
Herman, D. 2008. Events and event-types. Routledge Encyclopedia of Narrative Theory (2nd ed.). Eds. D. Herman, M. Jahn and M. L. Ryan. London: Routledge. 151-152.

Hewitt, L. E. 1995. "Anaphor in subjective contexts in Narrative Fiction". Deixis in Narrative. A Cognitive Science Perspective. Eds. J. F. Duchan, G. E. Bruder and L. E. Hewitt. Mahwah: Lawrence Earlbaum Associates. 325-340.

Hopper, P. J. 1979. "Aspect and foregrounding in discourse". Syntax and Semantics Vol. 12: Discourse and Syntax. Ed. T. Givón. New York: Academic Press. 213341.

Hopper, P. J. and S. A. Thompson. 1980. "Transitivity in grammar and discourse". Language 56: 251-299.

Huddleston, R. D. and G. K. Pullum. 2007. A Student's Introduction to English Grammar (2nd edn). Cambridge: Cambridge University Press.

Keeble, R. L. and J. Tulloch. 2012. Global Literary Journalism: Exploring the Journalistic Imagination. Evanston, Ill.: Northwestern University Press.

Kita, S. 2008. "Figure-Ground indeterminacy in descriptions of spatial relations: A construction grammar account". Crosslinguistic Perspectives on Argument Structure. Eds. M. Bowerman and P. Brown. London: Lawrence Earlbaum. 89-109.

Labov, W. 1972. Language in the Inner City. Philadelphia: University of Pennsylvania Press.

Langacker, R. W. 1987. Foundations of Cognitive Grammar, vol. I: Theoretical Prerequisites. Stanford: Stanford University Press.

Martínez, M. A. 2012. "-Ing supplementive clauses and narrative discourse referents". International Journal of English Studies IJES 12 (2) Special Issue: A New Approach to Literature: Corpus Linguistics: 73-91.

Prince, G. 2008. "Narrativehood, narrativity, narratability" Theorizing Narrativity. Eds. J. P. and J. A. García Landa. Berlin: de Gruyter. 19-27.

Propp, V. 1928. Morphology of the Folktale (2003 ed.) Austin: University of Texas Press.

Ryan, M. L., ed. 2004. Narrative across Media: The Languages of Storytelling. Lincoln: University of Nebraska Press.

Ryan, M. L. 2007. "Toward a definition of narrative". The Cambridge Companion to Narrative. Ed. D. Herman. Cambridge: Cambridge University Press. 22-35.

Sandford, A. J. and Emmott, C. 2012. Mind, Brain and Narrative. Cambridge: Cambridge University Press.

Sidner, C. L. 1983. "Focusing on the comprehension of definite anaphora". Computational Models of Discourse. Eds. M. Brady and R. Berkwick. Cambridge, MA: MIT Press. 267-233. 
Stockwell, P. 2002. Cognitive Poetics: An Introduction. London and New York: Routledge.

Talmy, L. 1975. "Figure and Ground in complex sentences". Proceedings of the First Annual Meeting of the Berkeley Linguistics Society, 419-430.

Talmy, L. 2000. Toward a Cognitive Semantics, Vol. I: Concept and Structuring Systems. Cambridge, Mass.: MIT Press.

Thompson, S. A. 1987. "Subordination and narrative event structure". Coherence and Grounding in Discourse. Ed. R. S. Tomlin. Amsterdam, Philadelphia: John Benjamins. 435-454.

Toolan, M. 1990. The Stylistics of Fiction: A Literary-Linguistic Approach. London and New York: Routledge.

Tsur, R. 2009. "Metaphor and figure-ground relationship: comparisons for poetry, music, and the arts". Cognitive Poetics: Goals, Gains, and Gaps. Eds. G. Brône and J. Vandaele. Berlin. Mouton de Gruyter. 237-277.

Van Dijk, T. A. 1986. "News schemata". Studying Writing: Linguistic Approaches. Eds. C. R. Cooper and S. Greenbaum. Beverly Hills, CA: Sage. 155-186.

Van Dijk, T. A. 1988. News as Discourse. Hillsdale, NJ: Erlbaum.

Van Gelderen, E. 2002. An Introduction to the Grammar of English. Amsterdam, Phil.: John Benjamins.

Verhaert, A. 2006. El Gerundio No-Perifrástico en Español: Cómo No Ser Demasiado Explícito Ni Demasiado Implícito. Amsterdam and New York: Rodopi.

Wallace, S. 1982. "Figure and Ground: the interrelationship of linguistic categories". Tense-Aspect: Between Semantics and Pragmatics. Ed. P. J. Hopper. Amsterdam, Phil.: John Benjamins. 201-223. 